\title{
Stakeholder Engagement as a Core Management Function: Analysing the Business Value of Stakeholder Engagement for Nigerian Business Organizations
}

\author{
Christopher Isike, Alice Ajeh \\ University of Zululand, South Africa, \\ Shell Petroleum Development Company, Nigeria \\ IsikeC@unizulu.ac.za
}

\begin{abstract}
This article examines the importance of adopting credible stakeholder engagement (SE) as a core management function, with particular reference to Nigerian business organizations. It used content analysis method to specifically examine the role of SE in business organizations; determine the utility of credible SE as a core management function rather than as an add-on; and trace measurable links between SE and business value (profit) with reference to selected multinational companies operating in Nigeria's Niger Delta region. The article situated its arguments within the Stakeholder Model of Business Value Creation, which it used as a conceptual analytical framework to justify why business organizations in the region should dedicate more attention and resources to quality SE for sustainable profitability. As the findings show, business organizations in the Niger Delta tend to treat SE as an add-on rather than as a core management function. Therefore, given the business value that effective SE adds to an organization, a paradigm shift is required. Business organizations in Nigeria should elevate SE to core management level with the requisite budget to make it fully functional.
\end{abstract}

Keywords: Business value, Business organizations, Management, Niger Delta, Stakeholder engagement

\section{Introduction}

In today's competitive global business environment, cooperative relationships with stakeholders enable firms to adapt, share risks and embrace innovation(Leadbeater, 2000). Indeed, the adage 'adapt or die' is as true in the business world as it is in the biological world. This is especially true in contemporary organizations characterized by "more diffuse decision making, accelerated informational flows and an emphasis on learning" due to technological advancement and globalization (Svendsen et al., 2001: 2; Castells, 2000). Technological advancement is acknowledged as a significant driver of the contemporary knowledge-based economy. The implications for stakeholder relations in strategically adding value to business are profound. Due to its growing "convergence of digital, mobile and social spheres, technological advancement is greatly shaping the dynamics of stakeholder relationships, connecting customers, employees and partners. It starts with chips and ends with trust" (Svendsen et al., 2001: 2; Castells, 2000). It is also arguably a source of creativity and innovation and, by extension, overall productivity and/or profitability. Against this backdrop, this article examines the importance of adopting credible stakeholder engagement (SE) as a core management function, with particular reference to Nigerian companies. It objectives are to [1] examine the role of SE in business organizations; [2] determine the utility of credible SE as a core management function rather than as an add-on; and [3] trace measurable links between SE and business value (profit) with reference to selected multinational companies operating in Niger Delta region Nigeria. The Stakeholder Model of Business Value Creation is used as a conceptual model.

A stakeholder can be defined as "any group or individual that can affect or is affected by the achievement of a corporation's purpose"(Freeman, 2004: 229). It includes "individuals or groups with which the corporation interacts who have a stake or a vested interest in it, such as employees, consumers, suppliers, and local communities within which corporations operate" (cited in Campbell, 2007: 947). Two categories of stakeholders are identified in the literature, namely primary or internal and secondary or external stakeholders. The primary/internal are those with a direct stake in a company's fortunes. Examples include shareholders and investors, employees, customers, suppliers, and residents of the communities where the company operates. Conversely, secondary stakeholders are those who "have indirect influences on an organization or are less directly affected by its activities," examples of which include "media and pressure groups, and others that inhabit the business and social networks of the organization" (Svendsen et al., 2001). Engaging these groups in a credible manner is increasingly becoming a business asset, rather than an add-on based on legal requirements or even moral obligation. Stakeholders have "'sufficient power' to affect the 
performance of the enterprise, either favourably or unfavourably", for instance through mobilizing social forces and/or withdrawing labour (Jeffery, 2009: 11).

The fait accompli approach to community engagement is becoming counter-productive for business organizations. An 'I know what is best for you' attitude deprives stakeholders of meaningful involvement in issues that affect them as well matters that they have an impact on. Hence, the idea of SE essentially rests on the notion that stakeholders "should be given the opportunity to comment and have input in the development of decisions that affect them" because "if they are not actively sought out, sooner or later they may demand to be consulted" (Jeffery, 2009). An example is Nike and child labour in the 1990s which was a human rights issue(Jeffery, 2009). Accordingly, in today's increasingly globalized world, SE describes "a broader, more inclusive, and continuous process between a company and those potentially impacted that encompasses a range of activities and approaches, and spans the entire life of a project" (International Finance Corporation, 2007: 3). Thus, SE has been defined by the Institute of Social and Ethical Accountability (ISEA)as "the process of seeking stakeholder views on their relationship with an organization in a way that may realistically be expected to elicit them"(ISEA, 1999).Such trust-based collaboration, "underpinned by the principle of accountability" (ISEA, 1999) is largely driven by respect for humanity and the common good of the stakeholders and the organization(Noland and Phillips, 2010: 40).

Stakeholder engagement is distinct from related concepts such as Stakeholder Management (SM), Stakeholder Salience (SS) and Corporate Social Responsibility (CSR). While SE is inclusive, interactive, continuous and yet open to change, SM is defensive, change-averse and hence, temporal(Jeffery, 2009). For its part, SS focuses mainly on identifying and prioritizing various stakeholders considering their divergent interests and impact, while SE is the actual relating with the identified stakeholder(Ihugba and Osuji, 2011: 28; Amaeshi, 2007). Similarly, SE is more than the traditional conception of CRS, because the former is a morally neutral concept. However, SE does not necessarily mean that an organization is more morally responsible (Greenwood, 2007). In other words, "although stakeholder engagement has moral elements, it is primarily a morally neutral activity"(Greenwood, 2007: 325).This has implications for the relevance of SE to business productivity because unless business organizations see $\mathrm{SE}$ as more than moral compulsion, they will be unable to adopt it as a core business strategy to reap the accompanying benefits. This requires that they embrace the various interactions that constitute the broader spectrum of stakeholder relations, a lack of which could render an organization unable to respond to the uncertainty that defines the business world (See Figure I). As Jeffery (2009) explains, when organizations are not pro-actively engaged with stakeholders, they are forced into a defensive position and have to employ reactive crises-management techniques, which cause long-term reputational damage, especially in relation to trust. Thus, "building a strong reputation helps an organization perform more effectively in the present and builds a reservoir of goodwill to draw upon in future crises" (IPSOS Public Affairs, 2011: 6).

Figure 1: Characteristics of Crisis Management, Stakeholder Management and Stakeholder Engagement

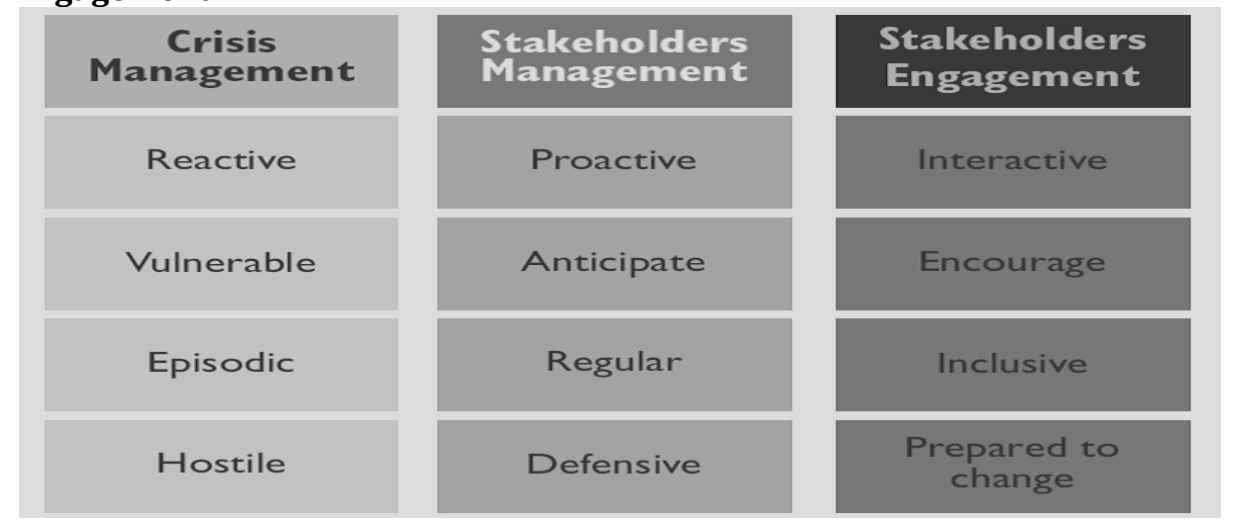

Source Jeffery (2009: 14) 
While studies have articulated the comparative financial advantages of a stakeholder-oriented business organization - especially through CSR - the non-financial advantages have not received sufficient attention. Yet, "if Corporate Responsibility is about minimizing negative and maximizing positive environmental and social impacts, then stakeholder engagement is one of the core skills and key activities which enables this to happen successfully and effectively. When organizations don't engage stakeholders successfully, they can lose out"(Jeffery, 2009: 3). The three-tier model for CSR outlined by Sethi (1975)entails [1] social obligation, [2] social responsibility and [3] social responsiveness. Viewed through the lens of social responsiveness, CSR takes stakeholder relations beyond mere obligation and/or norms. It recognizes that there are enormous benefits in adopting public relations as a core management technique. Corporate Social Responsibility has remained largely untapped by companies, largely due to the parochial focus on short-term benefits. Some business organizations tend to view and adopt CSR as an add-on, through the narrow prisms of obligation and/or philanthropy. Yet as Sethi's (1975) model suggests, it is not enough for companies to be stuck at the first level which is mere compliance. Rather, they should not only "recognize and internalize societal expectations" but "develop the competence to navigate uncertainty, maximize opportunity and engage effectively with external stakeholders on issues and concerns" (Svendsen et al., 2001: 4).

\section{Literature Review}

The literature on SE identifies various SE dynamics at global, regional and national levels(Harrison and Wicks, 2013; Beer and Rensburg, 2011; Jeffery, 2009; Greenwood, 2007; Perrini and Tencati, 2006; Svendsen et al., 2001; Hillman and Keim, 2001; Freeman, 2004). These studies show why organizations should take SE seriously in view of its long- and short-term implications for performance and the negative consequences of doing otherwise. For instance, Jeffery (2009) has argued that poor engagement "has the potential to undermine stakeholder relations resulting in mistrust and tension, as well as making the possibilities for future successful relations much more difficult". This is important as business organizations do not exist in a vacuum. Every business entity affects the society within which it exists, and is in turn impacted by the society. This symbiotic relationship is pertinent to the dynamics of a business organization and its ability to create value for the community. In today's business world, organizations can no longer "choose whether they want to engage with stakeholders or not; the only decision they need to take is when and how to engage successfully" (Jeffery, 2009: 13).

Scholars have developed various theories to assess if and why organizations focus on their stakeholders' interests alongside their own(Freeman, 2004; Campbell, 2007). The stakeholder theory defines the relationship between a firm and its stakeholders in terms of appropriate and inappropriate behaviour(Campbell, 2007: 949). Well-managed CSR balances stakeholders' wants and needs (SWANS) with those of the organization (OWANS) (Jeffery, 2009). The sometimes-disparate needs of different parties are efficiently reconciled to optimize long-term benefits, and value creation for the organization as well as the community. In the words of John Mackey, CEO of Whole Foods, "business is fundamentally a community of people working together to create value for not only themselves, but also for other people including their customers, employees, investors, and the greater society... Business owners and entrepreneurs ... need to ... manage their business more consciously for the well-being of all their major stakeholders while fulfilling their highest business purpose"(Quotedin Jeffery, 2009). The manifestation of SE could lie in commitment and loyalty towards employees as demonstrated by United Parcel Service or Dupont and Dofasco or credible engagement along the supply chain demonstrated by IKEA, Honda and Toyota. Vancity and Scotiabank's strong links with the community are another typical example, as are Shell Canada, Placer Dome and other companies' relationships with non-governmental organizations (NGOs) and communities (Svendsen et al., 2001: 4). The stakeholder theory thus shows how companies factor the protection of stakeholders into their decision making for improved productivity (Ihugba and Osuji, 2011).

Cummings (2001: 45) notes that three factors have been identified that underpin SE, namely managerialist, public interest and value shift orientations. A managerialist orientation is characterized by decision-makers 'quest to understand and pre-empt the views and opinions of stakeholders for the sake of business activities. It seeks to maximize shareholders' interests and resists change that is not geared towards this objective. Thus, even "If customers are unhappy, if accounting rules have been compromised, if product quality is bad, if environmental disaster looms, even if competitive forces threaten, the only interesting questions are whether 
and how these forces for change affect shareholder value, measured by the price of the stock every day"(Freeman et al., 2007: 4).On the other hand, a public interest orientation is characterized by an organization's pursuit of stakeholder interests, mainly due to legislative requirements and pressure. The driving force is compulsion be it moral, legal or otherwise. Given its fluid, reactionary, power-withholding features, the public interest approach is more reactive than proactive. Although there is some two-way information flow, SE is driven by the need to placate stakeholders(Ihugba and Osuji, 2011). At its best, public interest-driven engagements network with and relay information to stakeholders; however, the process is somewhat arbitrary. Finally, the value shift orientation involves a fundamental cultural shift in terms of what the organization's "role and indeed, their responsibilities to society should be"(Ihugba and Osuji, 2011: 31).This approach is characterized by stakeholder empowerment, giving them adequate information and independence. However, it is susceptible to "minority tyranny"(Ihugba and Osuji, 2011: 30). Here the level of SE is stakeholder control.

The state of Stakeholder Engagement among business organizations in Nigeria's Niger Delta: The various SE practices of business organizations in Nigeria are well documented (Idemudia, 2009; Hoben et al., 2012; Okonta and Douglas, 2001; Lugard, 2014).The common trend is a lack of inclusive and interactive engagement that is open and continuous(Onuoha, 2005; Lebura, 2013; Okonta and Douglas, 2001; Lugard, 2014).For example, in the oil-based economy of the Niger Delta, until the mid-2000s, the dominant multinational oil companies (MNOCs) (Shell, Chevron and NAOC) largely maintained a managerialist orientation, which was geared towards satisfying shareholders' interests. Before 2005 and 2006 when Chevron and Shell respectively adopted the Global Memorandum of Understanding (GMoU) model of community engagement, which gave communities a say in deciding their own development needs and implementing projects, both companies promoted CSR more out of social obligation than social responsiveness. In the heyday of militancy against MNOCs and government from the early 1990s up to themid-2000s, CSR was often practiced in response to global condemnation of their oil exploration activities, which were harmful to the environment, dislocated local economies and further impoverished the region's people (see Uzodike and Isike, 2009). Agitation for self-determination and control of resources in this oil-rich region led to frequent shutdown of their operations, resulting in huge financial losses(Okonta and Douglas, 2001). The companies' failure to adopt meaningful SE has been counter-productive for both the organizations and local communities, and has contributed to the perennial crises in the region.

Indeed, before 2005, MNOCs in the region adopted a managerialist orientation of SE, with a top-down approach to local stakeholders. According to Ihugba and Osuji (2011:30), "the power holders arrogate to themselves the status of tutor and proceed to falsely 'educate', persuade and advise the stakeholders. Such approaches deprive stakeholders of their voice and usually lead to outcomes most probably of no benefit to the stakeholders". The process is essentially non-participatory as stakeholders have no input; they are either not properly consulted or their inputs are inconsequential to the company's decisions. This non-consultative approach to SE results in what Lugard (2014) refers to as emotional inequity and a skewed playing field for framing CSR to achieve meaningful outcomes. This arguably explains the plethora of abandoned community development projects by business organizations in the Niger Delta. In many instances, some of these projects never got off the ground, exacerbating already existing distrust between communities and oil companies. In turn, this affected the company's licence to operate (LTO) and freedom to operate (FTO) in a number of communities with concomitant effects on new opportunities, productivity and profits. This underscores the need for broad support and goodwill from host communities beyond mere acceptance of business activities in their domain. According to Pyagbara (2010: 18), buy-in, support and goodwill are the main ingredients of the social licence and approval "required by any company seeking to conduct its business in a conflict-free environment and ensure the success of its investment". Such approval, which must be distinguished from other legal requirements such as "free, prior, and informed consent" (FPIC) ${ }^{1}$ is mainly granted by a host community and is also a function of a company's broader public image (Pyagbara, 2010).

ForIdemudia (2009), relationships between the various companies operating in the region and local communities have gone through three main phases. The first was characterised by the 'pay-as-you-go'

${ }^{1}$ This is a requirement of the United Nation's Declaration of the Rights of Indigenous People, Articles 19 and 32, which has now gained legal status (cited in Pyagbara, 2010:18). 
strategy where communities were largely kept at arm's length by the company, with little or no regard for CSR. Reaction in the form of protests and conflict over environmental degradation caused by oil-exploration activities shaped the contours of the second phase, which was characterized by some level of acceptance of the principle of CSR by MNOCs. Even then, the approach was largely devoid of sufficient community participation given its reliance on a few elite community representatives. As Lugard (2014: 169) argues, "this approach of settling some elites or traditional rulers without having to initiate projects or engage stakeholders with a view to collectively addressing the concerns of the major players spells doom for the stakeholders, particularly the IOCs who reportedly spent a whopping $\$ 3.7$ billion on security in the region in 2008 ". As a result, it has not only been unsustainable but has also perpetuated inter- and intra-community violence. The third phase was characterised by the idea of partnerships with a view to reduce costs and to improve on the previous phases as exemplified in the use of GMoUs as a model of community development. However, the success of this third phase has also remained questionable since it has not addressed community grievances in a sustainable manner (Idemudia, 2009). Arguably, one of the reasons is that the relationship lacks trust and cooperation based on deep community engagement in the developmental projects funded by companies. As Lugard (2014: 171) rightly observed, a stakeholder approach to CSR "would make the communities consider themselves as having a stake in the sustainability of CSR efforts, knowing full well that CSR programs and plans were designed by them and for them". However, 10 years after the introduction and operation of the GMoU by both Chevron and Shell, which has given communities power to decide on their own development programmes and thus deepened participation and trust, the ideal of real partnership is beginning to emerge (see Isike, 2016).

\section{Analytical framework: Stakeholder Model of Business Value Creation}

It is becoming evident that business organizations can no longer focus solely on maximizing profit, enhancing shareholder value and neglecting other stakeholders and still expect to remain viable. Evidence abounds of the detrimental effects of such an approach. Shareholder-oriented organizations tend to make narrow decisions which impact negatively on profits(Campbell, 2007). Globally, various events have reinforced, rather than reduced, the need for SE in the last 10 years (2005 to 2016). The economic downturn highlighted the uncertainty of the ever-changing global economic landscape. In the same vein, the information revolution presents a strong case for adequate stakeholder engagement for business organizations, especially multinational corporations whose increasing role in the global economy is widely acknowledged. As Castells, puts it, "the globally networked business model is at the vanguard of the information age just as the Ford Motor Company's assembly line was the icon of the industrial age"(Castells, 2000 cited in Svendsen et al., 2001:7). In the information age, almost everything relating to an organization is readily available to stakeholders and this fundamentally shapes their relationship with the organization in many ways. For example, with the internet becoming more affordable, aiding the circulation of information around the globe through multiple social media platforms, trust becomes a key component of good stakeholder relations. As Kelly aptly farmed it, "the network economy is founded on technology, but it can only be built on relationships" (cited in Svendsen et al., 2001:7).

By implication, the concept of CSR within the SE framework goes beyond the statutory obligations of organizations to comply with legislation as well as their usual approach of volunteerism and charity. Lugard (2014: 158), argues that the SE framework "helps other stakeholders assume emotional attachment or stakes in the sustainability of such corporate entity" and this is important for business success in terms of profits and sustainability.Business organizations that do not recognize this suffer a negative press and mobilization against the company, which affects their bottom-line and growth. The reaction of the Ravensthorpe and Hopetown communities in Western Australia to BHP Billiton's decision to shut down their nickel mine after only eight months of operation and that of the Slovenian public to the news of Renault's plan to close its operations in that country underscore the importance of engaging stakeholders for business survival and success (Jeffery, 2009). Sustaining reputation in an ever-changing business environment is a critical dimension that affects consumer preferences. As the IPSOS Public Affairs (2011: 2)study noted: your company's reputation with stakeholders influences consumers' desire to buy your products and/or services; the efficiency of your marketing spend; the credibility of your communications; employees' pride in working for you; investors' confidence to invest in you; legislators' inclination to help or hinder you; journalists' disposition to report positively or negatively about you; NGOs' propensity to work with or against you and 
people's willingness to hear your side of the story. All these reputational indicators create business value as they affect freedom and licence to operate.

Quality SE is thus a risk-mitigating tool and is more cost-effective and sustainable than the reactionary approach of crisis management (CM) as far as reputation building and sustenance are concerned. Little wonder then that Peter Drucker believes that proper 'social responsibility' of business "is to tame the dragon, that is, to turn a social problem into economic opportunity and economic benefit, into productive capacity, into human competence, into well paid jobs, and into wealth" (cited in Lugard, 2014: 159).The business value for both parties is noted in the stakeholder concept developed by Edward Freeman, who is regarded as the father of this concept(Fontaine et al., 2006). Freeman notes that, "to be an effective strategist you must deal with those groups that can affect you, and to be responsive (and effective in the long run), you must deal with those groups that you can affect" (Freeman, 2010: 46). His stakeholder theory and its further development by other scholars underscore the importance of moving beyond the traditional market-product strategic framework for efficiency and effectiveness. In his view, various external changes including increased foreign competition; environmental protection legislation; concerned groups with special interests; and the media, among others, have challenged the relevance of the narrow traditional approach. The stakeholder theory has gained traction since the 1980s.

The three dimensions of the stakeholder theory, namely, descriptive, instrumental and normative, are essential to the success of a business organization. From the descriptive point of view, the theory views cooperation as a "constellation of interests, sometimes competitive and sometimes cooperative", and analytically shows how multinational companies can "deal with these divergent interests of stakeholders"(Fontaine et al., 2006: 14). The instrumental perspective takes cognizance of the nexus "between the practice of stakeholder management and the achievement of various corporate governance goals", while the normative dimension identifies the moral guidelines of corporations 'activities and management(Fontaine et al., 2006: 14).The stakeholder is relevant in that, in the era of globalization, multinational companies are becoming more powerful (even more than states in many cases). Given their impact on society, their practices cannot be devoid of values and ethics. For such companies to remain viable, SE is critical since the wealth of the shareholder is dependent on the wealth of all stakeholders(Fontaine et al., 2006). According to Jeffery (2009), SE is characterized by a willingness to be open to change (See Figure 1 above). Jeffery rightly noted that "the ideal stakeholder engagement process should be iterative; allowing engagement to benefit from diligent planning, thorough reporting and the application of learning as a result of appropriate evaluation and monitoring"(Jeffery, 2009: 15). It is also interactive in nature; encouraging holistic and inclusive planning that might not only lead to new market opportunities but also enhance the organization's ability to mitigate risk given its preparedness for change. Hence, it is not merely defensive or risk averse. The notion of risk mitigation is appropriate given the lasting implications of reputational damage in the event of a crisis that undermines credible SE and the cost of image rebuilding for such companies. Consider for instance, the reputational and financial damage suffered by McDonalds, Mitsubishi, Monsanto, Nestlé, Nike, Shell, and Texaco following public awareness campaigns by advocacy stakeholder groups against some of their business practices which could have been avoided through effective SE(cited in Svendsen et al., 2001: 9). With the advancement of technology, it takes only a click of a mouse to disseminate information that can damage the reputation of a company around the globe. The financial and other costs of repairing such damage are enormous including the possible loss of human capital. Re-investing in reputation may involve retrenching and/or employing extra staff; advertising spend and excessive compensation claims. The human rights controversies around Nike's supply chain; and Shell's investment in public relations post-Brent Spar and Nigeria as well as Texaco's handling of the charge of systematic racism in the US are cases in point which underscore the business value of effective SE (Svendsen et al., 2001; Fontaine et al., 2006).

In this way, the notion of reputation capital is now considered as a core business asset in its own right, and an important determinant of business success in the discourse of SE(Svendsen et al., 2001). For instance, Cone and Ropper's study, which focuses on consumer attitudes at national level, found that $76 \%$ of consumers were likely to switch to a brand reputed to be for a good cause. Similarly, the value of the stock of a company accused of wrong doing was shown to have a high likelihood of a downturn (cited in Svendsen et al., 2001). Thus, "engaging with stakeholders from the start - as part of your core business strategy - enables a proactive cultivation of relationships that can serve as 'capital' during challenging times" (International 
Finance Corporation, 2007: 6).Furthermore, in terms of innovation positive relationships between various stakeholders (i.e., management, employers, and the community) create space for creativity and innovation. Nahaphiets and Ghoshal note that "no matter how knowledgeable employees are, if they believe they are working in a hostile, low-trust environment they will hoard information, avoid collaboration, and display very low levels of creativity" (cited in Svendsen et al., 2001: 10). Given that no individual employee is the sole repository of knowledge, sharing and collaboration among employees, which is usually fostered by an environment of trust, it is essential to facilitate innovation (Nahapiet and Ghoshal, 1998). An innovative work team is largely a function of a positive relationship between both management and employees, and employees themselves (Cooke and Wills, 1999; Svendsen et al., 2001). Jeffery (2009: 3) also noted that, meaningful SE gives employees the requisite skills to negotiate long-term satisfaction and benefits. In summary, a range of benefits is associated with credible SE. John Kotter and James Heskett demonstrated that stakeholder-oriented companies achieved four times more sales growth and eight times more employment growth over an eleven-year period, than their shareholder-focused counterparts (cited in Svendsen et al., 2001:11). The study focused on the interests of a broad mix of stakeholders rather than shareholders as the mark of visionary and successful companies. In the broad sense, four key benefits were found to emanate from credible stakeholder engagement: better shareholder risk management; innovation; new markets and opportunities and reputational focus. With reference to shareholder risk, Monsanto's diminutions of license to operate in certain markets in Europe and Shell's "diminution of suppliers or employer of choice status" following the twin shock of Brent Spar and Nigeria, are cases in point(Svendsen et al., 2001:12). Freeman et al. (2007: 2) have also argued that "the primary responsibility of the executive is to create as much value for stakeholders as possible, and that no stakeholder interest is viable in isolation of the other stakeholders."

\section{Measurable links between stakeholder engagement and business value for Nigerian business organizations}

A study by the former director of the Clarkson Centre for Business Ethics at the University of Toronto, shows that organizations that focus only on shareholders "lack information from stakeholders and the environment that would allow them to anticipate opportunities and solve problems when they are small and less costly to remedy" (Clarkson cited in Svendsen et al., 2001). The same study revealed that companies that place a premium on socially responsible behaviour made the most money. Indeed, as Sethi observed, credible SE assists in "achieving good levels of customer satisfaction, employee morale, returns to investors and reducing environmental impacts of operations, products and services" (cited in Svendsen et al., 2001). All of these call for the adoption of meaningful, credible SE as a core management strategy given that it confers a comparative advantage on business organizations that take it seriously. Other studies have shown a positive correlation between good stakeholder engagement and financial performance (Roman et al., 1999; Waddock and Graves, 1997; Soana, 2011; Collins and Porras, 2005). How this plays out in the context of Nigeria is the focus of this sub-section.

As noted earlier, Nigerian business organizations' approach to CSR has been predominantly philanthropic and this undergirds how they relate to their stakeholders. It also partly explains the relative failure of some of these business organizations (both local and international) to sustainably address the problems of poverty, degradation and deprivation in the communities where they operate despite their investment in development initiatives. At the core of such failure is the lack of engagement and involvement of stakeholders, especially the host community, which has the power to confer or withhold the social licence for smooth operation of companies. Although Lugard (2014:) argues that "most of such efforts are arguably palliative and tokenistic", the foregoing theoretical discussion suggests that credible SE adds business value to organizations by reducing constraints on the license to operate and freedom to operate. This is relevant for business organizations in Nigeria, especially MNOCs operating in the Niger Delta region. Since the 1990s, the region has been characterized by community agitation and armed conflict, which resurfaced in 2016 (Isike, 2016). It thus presents a practical case to understand the importance of adopting credible SE as a core business strategy. This would not only create a win-win situation for both shareholders and stakeholders, but would help to forestall violence and engender peace as communities begin to regard themselves as real stakeholders in the oil business. 
Gaining and sustaining this social licence and approval is mainly possible through credible and quality SE, which Shell and other companies in the region have largely fallen short of but are now beginning to correct through the GMoU model of community engagement. Given the rise in human and environmental rights violations engendered by the weak regulatory framework provided to the oil companies by corrupt political elites, the Ogoni people and others in the region began to perceive Shell as an oppressive alliance with the majority controlled-government. This perception gained credibility with the militarization of the region as Shell called for security officers (then referred to as riot police), fracturing the relationship between the company and the people. The company was also seen as disrespecting community opinions and culture, demonstrated by the arrogance of some of its staff; its operation in sacred shrines and forest although permitted by Nigerian law; and the imposition of its 'civilised values' (Uzodike and Isike, 2009). This clearly violates Freedman's view of stakeholders as "constituent to be consulted rather than spectators to be ignored"(Harting et al., 2006: 43). The highly questionable arrest, trial and hanging of the Ogoni activist, Ken Saro-Wiwa and eight Ogoni compatriots, was a high point in the Niger Delta crises, which did a lot of harm to the public image of the oil companies operating in the region as they did little to avert the situation. In the Niger Delta region, "local communities have not been fully incorporated into deciding on the best initiatives for them and how to effectively frame, design and implement these initiatives to deliver sustainable results"(Lugard, 2014: 171).Multinationals' tokenistic and fragmented CRS efforts are disconnected from their business strategy and have not been able to generate the required emotional equity in the community to support their operations. As Lugard (2014:172) notes, "the crux of the emotional equity proposition is hinged on the inevitability of a shift from performance structured CSR to engagement. When people are engaged in such undertakings, they buy into the business' corporate objectives and the sustainability of same, not because they are shareholders, but because their attainment of their personal and community goals is tied to the existence of such business entities."

\section{Conclusion}

Focusing on the Niger Delta, we have argued that business organizations in Nigeria, tend to treat SE as an add-on rather than as a core management function. Given the business value that effective SE adds to an organization, a change in mind-set is required. Business organizations in Nigeria should elevate SE to core management level with the requisite budget to make it fully functional. As a tangible risk-mitigating mechanism, quality SE allows business organizations not only to plan for the future but to better understand critics and potentially refute, convince or address criticisms (Jeffery, 2009). Jeffery therefore justifies the need for investment of time and money in SE based on its potential to reassure stakeholders that the organization is on top of the issues. In such a scenario, both the organization and stakeholders protect the interests of the organization. This is crucial in the fast-changing political, economic, social, technological and environmental context of business organizations, where there is a need to simultaneously maximize economic, social, and environmental values (Jeffery, 2009; Svendsen et al., 2001). Well-planned SE maximizes innovation and mitigates both technical and non-technical risks. Therefore, "corporations must proactively engage with local stakeholders to determine their pressing needs, allow them to take part in framing CSR responses to ultimately reflect stakeholders' inputs in the resulting CSR program. This will provide a sense of ownership which is necessary for local communities to support and protect any resulting CSR program thereby reducing the usual scepticism associated with corporate CSR efforts"(Lugard, 2014:171-172).It is for this reason Drucker suggested that the operational challenges and infrastructural needs of community stakeholders be moved from the liability column to asset column through CSR undertakings targeted at meeting some of these needs and not just for window-dressing (Lugard, 2014:173).Thus, rather than being a nice thing to have, 'a good way to manage crises' or a cosmetic add-on, meaningful SE is "an essential and mutually beneficial strategic function that results in better-informed and more effective policies, projects, programs and services"(DCFS, 2013: 1). It is thus, recommended that, business organizations in Nigeria dedicate more time and resources to quality SE for sustainable profitability.

\section{Reference}

Amaeshi, K. (2007). Exploring the institutional embeddedness of corporate stakeholding and social responsibility: a comparative political economy perspective, Unpublished Doctoral Dissertation, Business School, University of Warwick, Warwick 
Beer, E. \& Rensburg, R. (2011). Towards a theoretical framework for the governing of stakeholder relationships: a perspective from South Africa. Journal of Public Affairs,11(4), 208.

Campbell, J. L. (2007). Why would corporations behave in socially responsible ways? An institutional theory of corporate social responsibility. Academy of Management Review,32(3), 946-967.

Castells, M. (2000). The Rise of the Network Society,Malden: Blackwell Publishers.

Collins, J. C. \& Porras, J. I. (2005). Built to last: Successful habits of visionary companies,London: Random House.

Cooke, P. \& Wills, D. (1999). Small firms, social capital and the enhancement of business performance through innovation programmes.Small Business Economics,13(3), 219-234.

Cummings, J. (2001). Engaging stakeholders in corporate accountability programmes: A cross-sectoral analysis of UK and transnational experience.Business Ethics: A European Review,10(1), 45-52.

DCFS. (2013). Stakeholder Engagement Tools For Action. Los Angeles: Center for the Study of Social Policy.

Fontaine, C., Haarman, A. \& Schmid, S. (2006). The stakeholder theory.Edlays Education, 1, 1-33.

Freeman, R. E. (2004). The stakeholder approach revisited.Zeitschrift für Wirtschafts-und Unternehmensethik,5(3), 228.

Freeman, R. E. (2010). Strategic Management: A Stakeholder Approach,Cambridge: Cambridge University Press.

Freeman, R. E., Harrison, J. S. \& Wicks, A. C. (2007). Managing for Stakeholders: Survival, Reputation, and Success,Yale: Yale University Press.

Greenwood, M. (2007). Stakeholder engagement: Beyond the myth of corporate responsibility.Journal of Business Ethics, 74(4), 315-327.

Harrison, J. S. \& Wicks, A. C. (2013). Stakeholder theory, value, and firm performance.Business Ethics Quarterly, 23(1), 97-124.

Harting, T. R., Harmeling, S. S. \& Venkataraman, S. (2006). Innovative stakeholder relations: When "ethics pays"(and when it doesn't).Business Ethics Quarterly,16(1), 43-68.

Hillman, A. J. \& Keim, G. D. (2001). Shareholder value, stakeholder management, and social issues: what's the bottom line?Strategic Management Journal, 22(2), 125-139.

Hoben, M., Kovick, D. \& Plumb, D. (2012). Corporate and Community Engagement in the Niger Delta: Lessons Learned from Chevron Nigeria Limited's GMOU Process, Washington, DC: Consensus Building Institute.

Idemudia, U. (2009). Assessing corporate-community involvement strategies in the Nigerian oil industry: An empirical analysis.Resources Policy, 34(3), 133-141.

Ihugba, B. U. \& Osuji, O. K. (2011). Corporate Citizenship and Stakeholder Engagement: Maintaining an Equitable Power Balance.Electronic Journal of Business Ethics and Organization Studies, 16(2), 28-38.

International Finance Corporation. (2007). Stakeholder Engagement: A Good Practice Handbook for Companies Doing Business in Emerging Markets, World Bank Group.

IPSOS Public Affairs. (2011). Your Stakeholders and Your Reputation.

ISEA. (1999). AccountAbility 1000 (AA1000): Standard, guidelines and professional qualification,London: Institute of Social and Ethical AccountAbility.

Isike, C (2016). Women, inclusiveness and participatory governance in Nigeria's Niger-Delta: a focus

on Shell's model of community development in the region", Journal of Social Sciences, 49(3), 205 - 214

Jeffery, N. (2009). Stakeholder Engagement: A Road Map to Meaningful Engagement,Doughty Centre, Cranfield School of Management.

Leadbeater, C. (2000). Living on thin air: The new economy, London: Penguin.

Lebura, S. (2013). Stakeholder Relationships in the Nigerian Oil Industry, Unpublished Doctoral, Business And Law, De Montfort University, Leicester

Lugard, S. B. (2014). Stakeholder approach to corporate social responsibility: recipe for sustainable peace in the Niger Delta region?Journal of Sustainable Development Law and Policy, 4(1), 154-173.

Nahapiet, J. \& Ghoshal, S. (1998). Social capital, intellectual capital, and the organizational advantage.Academy of Management Review, 23(2), 242-266.

Noland, J. \& Phillips, R. (2010). Stakeholder engagement, discourse ethics and strategic management.International Journal of Management Reviews, 12(1), 39-49.

Okonta, I. \& Douglas, O. (2001). Where Vultures Feast: Forty Years of Shell in the Niger Delta: Environmental Rights Group/Friends of the Earth, Nigeria. 


\section{Journal of Economics and Behavioral Studies (ISSN: 2220-6140)}

Vol. 9, No. 1, pp. 46-55, February 2017

Onuoha, A. (2005). From Conflict to Collaboration:Building Peace in Nigeria's Oil Producing Communities,London: Adonis \& Abbey.

Perrini, F. \& Tencati, A. (2006). Sustainability and stakeholder management: the need for new corporate performance evaluation and reporting systems.Business Strategy and the Environment, 15(5), 296308.

Pyagbara, L. S. (2010). Shell's Social Licence to Operate: A Case Study of Ogoni Movement for the Survival of the Ogoni People. In: ECCR (ed) Shell in the Niger Delta: A Framework for Change, Five case studies from civil society. Oxford: The Ecumenical Council for Corporate Responsibility(ECCR).

Roman, R. M., Hayibor, S. \& Agle, B. R. (1999). The relationship between social and financial performance: repainting a portrait.Business \& Society, 38(1), 109-125.

Sethi, S. P. (1975). Dimensions of corporate social performance: An analytical framework. California management review, 17(3), 58-64.

Soana, M. G. (2011). The relationship between corporate social performance and corporate financial performance in the banking sector. Journal of Business Ethics,104(1), 133-148.

Svendsen, A. C., Boutilier, R. G. \& Abbott, R. M. (2001). Measuring the business value of stakeholder relationships, Part One, Toronto, Ontario: the Canadian Institute of Chartered Accountants.

Uzodike, N. \& Isike, C. (2009). Whose Security? Understanding the Niger-Delta conflict as a clash of two security conceptions. African Security Review, 18(3), 103-111

Waddock, S. A. \& Graves, S. B. (1997). The corporate social performance-financial performance link.Strategic Management Journal, 18(4), 303-319. 